\title{
Proximate and Phytochemical Compositions of Leaf and Root of (Cattle Stick) Carpolobia lutea G. Don
}

\author{
*OLAYINKA, BU, OGUNGBEMI, RF; ABINDE, OO; LAWAL, AR; \\ ABDULRAHAMAN, AA; ETEJERE, EO
}

\author{
Department of Plant Biology, Faculty of Life Sciences, University of Ilorin, P.M.B. 1515, Ilorin, Nigeria \\ *Corresponding Author Email: olayinka.bu@unilorin.edu.ng
}

\begin{abstract}
Carpolobia lutea is a medicinal plant commonly utilized in Nigeria to boost libido. The ethnomedicinal importance of any plant lies in some secondary metabolites. Hence, the present study was carried out to investigate the proximate and phytochemical composition of roots and leaves of this plant using standard methods. The proximate composition of leaves and roots showed moisture, ash, fibre, protein, fat and carbohydrate contents with values that ranged between $8.84-9.55,3.48-3.65,1.10-1.06,6.64-8.39,1.80-1.80$ and $76.16-77.47 \%$ respectively. The leaves contained higher amount of ash, crude protein and fat than the roots. The results of ethanolic extracts showed the presence of alkaloids, anthraquinones, steroids, saponins, tannins, phenols, terpenoids, anthocyanin, carotenoids and flavonoids in both the leaves and roots. These phytochemicals were found to be significantly higher in roots except for anthraquinones, flavonoids and steroids which were significantly higher in the leaves. Among the phytochemicals, alkaloids were found to be highest in concentration followed in decreasing order by saponins, steroids, tannins, flavonoids, anthraquinones, anthocyanin, terpenoids, phenols and carotenoids. The results indicated that, $C$. lutea leaf and root have high nutritive and medicinal values and this could be explored for pharmaceutical purposes.
\end{abstract}

\section{DOI: https://dx.doi.org/10.4314/jasem.v23i1.9}

Copyright: Copyright (c) 2019 Olayinka et al. This is an open access article distributed under the Creative Commons Attribution License (CCL), which permits unrestricted use, distribution, and reproduction in any medium, provided the original work is properly cited.

Dates: Received: 19 March 2018; Revised: 07 January 2019; Accepted 13 January 2019

Keywords: Alkaloids, Steroids, Carbohydrate, Crude fibre, Carpolobia lutea.

Carpolobia lutea is a member of the family Polygalaceae. It is widely distributed in west and central areas of tropical Africa where it occurs as an evergreen shrub or tree of $5 \mathrm{~m}$ height (Akpan et al., 2012). The plant is a popular aphrodisiac herbal medicine. Various studies had reported and described the following uses of the plant such as curing of male sterility, increasing libido and induction of penile erection (Manfo et al., 2011). In the Efik area of Nigeria, the root and the stem are chewed at night before bed time to boost libido (Etukudo, 2003).

Other ethnomedicinal uses include use of the root decoction as an aphrodisiac in the case of paroxetineinduced sexually dysfunction in sexually active male rats as well as treatments of genitourinary infections, gingivitis and waist pain (Ettebong and Nwafor, 2009; Yakubu and Jimoh, 2014). It is also used as an analgesic, curing of rheumatism, fever, insanity, dermal infections, venereal diseases, sterility, as a taeniafuge and vermifuge as well as facilitation of child birth (Muanya and Odukoya, 2008). The plant possesses anti-inflammatory, anti-arthritic and antimicrobial activities (Iwu and Anyanwu, 1982; Ettebong and Nwafor, 2009). Ettebong et al. (2011) have established the contraceptive, estrogenic, and antiestrogenic potentials of the methanolic root extract of the plant in rodents. The leaf is used in the management of fever, headache, leprosy, snake bite, venereal disease, and wound (Ajibesin et al., 2007). The stem is used as chewing stick for oral hygiene (Kayode and Omotoyinbo, 2008). Literatures abound had revealed great details on the medicinal importance of C.lutea while ignoring the proximate and phytochemical constituents. It is therefore the focus of this study to provide information on the proximate and phytochemical constituents most importantly the leaf and root of $C$. lutea which have been variously reported to be of immense medicinal values.

\section{MATERIALS AND METHODS}

Description of the Plant: $C$. lutea commonly known as cattle stick (English), Ikpafun (Ibibio), Agba or Angalagala (Igbo-Eastern Nigeria) and Oshunshun (Yoruba - Western Nigeria). The leaf is simple and 2 - $7.5 \mathrm{~cm}$ long, 1-2.8 cm broad; branches and mid-rib densely pubescence; lamina variable in shape, ovate, ovate-elliptic, oblong, or narrowly elliptic, obtuse or

*Corresponding Author Email: olayinka.bu@unilorin.edu.ng 
rounded at the base. The flower is zygomorphic, often brightly coloured. The fruit is fleshly yellow or red. The seeds have a copious fleshy endosperm (Hutchinson and Dalziel, 1954).

Collection and Preparation of Plant Samples: The leaves and roots were collected from Oja-tutun market, in Ilorin, Kwara State, Nigeria. The plant was authenticated at the Herbarium unit of the Department of Plant Biologyof the University of Ilorin, Ilorin, Kwara State, Nigeria. The leaves and roots were oven-dried at $80^{\circ} \mathrm{C}$ for 2 hours and ground using mortar and pestle till a uniform powdery form was achieved.

Extraction Procedure: The ethanolic extract of the samples were achieved by soaking $20 \mathrm{~g}$ each of powdered samples of leaves and roots in $100 \mathrm{ml}$ of ethanol in different air-tight, properly labelled glass containers. These were left undisturbed at a temperature of $28 \pm 2^{\circ} \mathrm{C}$ for 120 hours (5 days). After this, the extracted samples were filtered with a clean white sieving cloth into separate $100 \mathrm{ml}$ conical flasks. The extracts were separately filtered again using Whatman filter paper folded appropriately into a funnel. The filtrates were then poured into separate $100 \mathrm{ml}$ beakers and were labelled. Afterwards, the extracts were evaporated at $45^{\circ} \mathrm{C}$ in an oven so as to concentrate them to $15 \mathrm{ml}$. Each concentrated extract was poured into different $3 \mathrm{ml}$ glass bottles, labelled and the yield of each extract was then subjected to various analytical procedures.

Proximate Analysis: Proximate analysis was carried out following the procedure of Association of Official Analytical Chemist (AOAC, 2000). This was done to determine the six parameters such as moisture, ash, fibre, protein, fat and carbohydrate (expressed as percentage) present in the samples.

Qualitative and Quantitative Phytochemical Examination: Qualitative and quantitative phytochemical screening carried out on the ethanolic extracts of the samples to test for the presence of secondary metabolites and the methods were adapted from the previous of work of plant analysis by Odebiyi and Sofowora (1979) and Onwuka (2005). The bioactive substances determined were alkaloids, anthraquinones, flavonoids, saponins, tannins, phenols, steroids, anthocyanin, terpenoids and carotenoids. Each of the constituents was calculated in milligram per 100 $\mathrm{g}$ of the sample and in triplicates for each of the samples.

Data Analysis: Data were analysed using Statistical Package for Social Science (SPSS) software version 16. Significant differences among the plant parts (leaf and root) from means of three replicates were separated using t-test at $5 \%$ level of probability.

\section{RESULTS AND DISCUSSION}

The results of proximate composition of $C$. lutea plant parts showed that percentage moisture, ash, crude protein, crude fat, crude fibre and carbohydrate ranged from $8.8-9.6 \%, 3.5-3.6 \%, 6.6-8.4 \%, 1.8-1.9 \%, 1.10 \%$ and $76.2-77.5 \%$, respectively (Table 1). Moisture and carbohydrate contents were significantly higher in the root than in the leaf. While the ash, crude protein, crude fat and crude fibre contents were significantly higher in the leaf than that of root. Among the proximate parameters, regardless of the plant parts, carbohydrate recorded the maximum mean value of $76.8 \%$ followed by moisture, crude protein, ash, crude fat and crude fibre with respective mean values of $9.2 \%, 7.5 \%, 3.6 \%, 1.8 \%$ and $1.1 \%$ (Table 1). The foregoing results had revealed that leaves and roots of $C$. lutea were very rich in carbohydrates when compared to plants such as Acalypha sp.and Tithonia diversifolia where the carbohydrate contents ranged between 38.2-52.3\% (Iniaghe et al., 2009; Olayinka et al., 2015). The moisture contents of leaves and roots could be considered to be low and this would hinder the growth of microorganisms and increase the shelf life (Adeyeye and Ayejuyo, 1994). The protein content which was found to be high in amount in the leaves is relatively lower when comapred those recorded from leafy vegetable Talinum triangulare $(31.0 \%)$ and nonconventional leafy vegetables such as Hibiscus cannabinus and Heamatostaphis bateri (12.4-13.8\%) (Akindahunsi and Salawu, 2005; Kubmarawa et al., 2009).

Table 1: Proximate composition of leaf and root of Carpolobia lutea.

\begin{tabular}{|c|c|c|c|c|}
\hline Proximate composition (\%) & Leaf & Root & Mean & P-value \\
\hline Moisture & $8.84 \pm 0.01^{\mathrm{b}}$ & $9.55 \pm 0.01^{\mathrm{a}}$ & $9.20 \pm 0.01$ & $<0.001$ \\
\hline Ash & $3.65 \pm 0.01^{\mathrm{a}}$ & $3.48 \pm 0.01^{\mathrm{b}}$ & $3.57 \pm 0.01$ & $<0.001$ \\
\hline Crude protein & $8.39 \pm 0.01^{\mathrm{a}}$ & $6.64 \pm 0.01^{\mathrm{b}}$ & $7.52 \pm 0.01$ & $<0.001$ \\
\hline Crude fat & $1.86 \pm 0.01^{\mathrm{a}}$ & $1.80 \pm 0.01^{\mathrm{b}}$ & $1.83 \pm 0.01$ & $<0.002$ \\
\hline Crude fibre & $1.10 \pm 0.01^{\mathrm{a}}$ & $1.06 \pm 0.01^{\mathrm{b}}$ & $1.08 \pm 0.01$ & $<0.008$ \\
\hline Carbohydrate & $76.16 \pm 0.01^{b}$ & $77.47 \pm 0.01^{\mathrm{a}}$ & $76.82 \pm 0.01$ & $<0.001$ \\
\hline
\end{tabular}

The ash contents of the leaves and roots were relatively lower than those recoded from Tithonia diversifolia (8.1-12.5\%) and some vegetables such as Occimum graticimum (8.0\%) and Hibiscus esculentus 
(8.0\%) (Akindahunsi and Salawu, 2005; Olayinka et $a l ., 2015)$. It should be noted that the ash content is a reflection of the mineral elements preserved in any food materials (Iniaghe et al., 2009). The crude fat in the leaves was lower when compared to those values recorded for Tithonia diversifolia leaves (2.4\%). However, higher amount of crude fat was recorded from the roots than that recorded for Tithonia diversifolia roots $(0.8 \%)$ (Olayinka et al., 2015). Leaves and roots of $C$. lutea can be ranked to be a poor source of fibre as demonstrated in this study. This could be attributed to high carbohydrate contents. Non-starchy vegetables are the richest sources of dietary fibre (Agostoni et al., 1995).

Phytochemical qualitative tests revealed the presence of alkaloids, anthraquinones, flavonoids, saponins, tannins, steroids, anthocyanin, carotenoids, phenols and terpenoids in both the leaves and roots samples of
C. lutea in varying concentration. Some of these phytochemicals most importantly alkaloids, saponins, steroids, flavonoids have been established to be of high medicinal values (Oloyede, 2005). C. lutea enjoys extensive patronage as herbal medicine among the Yoruba, Ibo, Efik and Ijaw people of Nigeria because of its aphrodisiac potential. The ability of the plant to boost libido could be attributed to the presence of steroids. Steroidal compounds have significant importance in pharmaceutical industry due to their relationship with sex hormones (Okwu, 2001). Similarly, anti-microbial and antiinflammatory activities of the plant could be attributed to the presence of flavonoids and terpenoids (Alan and Miller, 1996; Doughari, 2012).

Quantitatively, significant differences were not recorded in all the phytochemical compounds between the plant parts investigated except for alkaloids, anthraquinones and saponins (Table 2).

\begin{tabular}{|c|c|c|c|c|}
\hline $\begin{array}{l}\text { Phytochemical } \\
\text { composition }(\mathrm{mg} / 100 \mathrm{~g})\end{array}$ & Leaf & Root & Mean & P-value \\
\hline Alkaloids & $1.21 \pm 0.01^{\mathrm{b}}$ & $1.26 \pm 0.01^{\mathrm{a}}$ & $1.24 \pm 0.01$ & $<0.004$ \\
\hline Anthraquinones & $0.20 \pm 0.01^{\mathrm{a}}$ & $0.09 \pm 0.01^{\mathrm{b}}$ & $0.15 \pm 0.01$ & $<0.001$ \\
\hline Flavonoids & $0.19 \pm 0.01^{\mathrm{a}}$ & $0.17 \pm 0.01^{\mathrm{a}}$ & $0.18 \pm 0.01$ & $<0.070$ \\
\hline Saponins & $0.36 \pm 0.01^{\mathrm{b}}$ & $0.54 \pm 0.01^{\mathrm{a}}$ & $0.45 \pm 0.01$ & $<0.001$ \\
\hline Tannins & $0.26 \pm 0.01^{\mathrm{a}}$ & $0.27 \pm 0.01^{\mathrm{a}}$ & $0.27 \pm 0.01$ & $<0.288$ \\
\hline Steroids & $0.42 \pm 0.01^{\mathrm{a}}$ & $0.40 \pm 0.01^{\mathrm{a}}$ & $0.41 \pm 0.01$ & $<0.070$ \\
\hline Anthocyanin & $0.09 \pm 0.01^{\mathrm{a}}$ & $0.10 \pm 0.01^{\mathrm{a}}$ & $0.10 \pm 0.01$ & $<0.288$ \\
\hline Carotenoids & $0.02 \pm 0.01^{\mathrm{a}}$ & $0.03 \pm 0.01^{\mathrm{a}}$ & $0.03 \pm 0.01$ & $<0.288$ \\
\hline Phenols & $0.04 \pm 0.01^{\mathrm{a}}$ & $0.05 \pm 0.01^{\mathrm{a}}$ & $0.05 \pm 0.01$ & $<0.288$ \\
\hline Terpenoids & $0.08 \pm 0.01^{\mathrm{a}}$ & $0.09 \pm 0.01^{\mathrm{a}}$ & $0.09 \pm 0.01$ & $<0.288$ \\
\hline
\end{tabular}

The roots of $C$. lutea had significantly higher $(p<0.05)$ concentration of alkaloids and saponins than the leaves. Conversely, the leaves showed significantly greater concentration of anthraquinones when compared to the values recorded from roots (Table 2). Alkaloids were the highest occurring secondary metabolite in the plant parts studied followed by saponins, steroids, tannins, flavonoids, anthraquinones, anthocyanins, terpenoids, phenols and carotenoids (Table 2). The high concentration of alkaloids in roots and leaves of $C$. lutea over other phytochemicals could be attributed to its stimulating and wound healing properties (Mitaine-Offer et al., 2002; Ajibesin et al., 2007). The presence of tannins is not misnomer as this compounds have been found to be widely distributed in plants. Anthraquinones are generally used as dyes and are also known as antibacterial agents (Aiyelaagbe and Osamudiamen, 2009). Tannins are useful in wound healing (Kar, 2007), as astringent and antimicrobial (Singhal, 2001). Anthocyanin, terpenoids, phenols and carotenoids were found to be lower in amounts when compared with other phytochemicals. Anthocyanins have been shown to possess several therapeutic benefits such as anti-cancer and anti-neoplastic properties (Karaivanova et al., 1990; Kamei et al., 1995). Terpenoids have anti-inflammatory and antimicrobial as well as neurotoxic actions (Doughari, 2012). Phenols play a role in plant defence against pathogen and herbivores while carotenoids are important dietary source of vitamin A (Paiva and Russel, 1999).

Conclusion: The present investigation showed that variation exists in the concentration of both proximate and phytochemical components of $C$. lutea leaves and roots. Furthermore, most of these constituents were found to be higher in roots than in leaves. All these phytochemicals are active and are responsible for various effects of the plant. Further studies are needed to ascertain which phytochemicals among those identified are responsible for the aphrodisiac and other biological effects of the plant. These would lend firm credence to the ethnomedicinal uses of the leaf and root among the Ibo, 
Efiks, Ijaw, and Yoruba of Nigeria and the Pygmies of Cameroon.

\section{REFERENCES}

Adeyeye, E. and Ayejuyo, O. (1994). Chemical composition of Cola acuminata and Garcinia kola seeds grown in Nigeria. Int. J. Food Sci. Nutr., 45: 223-230.

Agostoni, C; Riva, R; Giovanni, M (1995). Dietary fiber in weaning foods of young children. Pediatrics, 96: 1000-1005.

Aiyelaagbe, O.O. and Osamudiamen, P.M. (2009). Phytochemical screening for active compounds in mangiferaindica leaves from Ibadan, Oyo State. Plant Sci Res, 2(1): 11-13.

Ajibesin, K.K., Ekpo, A.B.; Bala, D.N., Essien, E.E. and Adesanya, S.A. (2007). Ethnobotanical survey of Akwa Ibom State of Nigeria. $J$. Ethnopharmacol, 115: 387-408.

Akindahunsi, A.A. and Salawu, S.O. (2005). Phytochemical screening and nutrient and antinutrient composition of selected tropical green leafy vegetables. Afr. J. Biotechnol., 4: 497-501.

Akpan, M.M., Okokon, J.E. and Akpan, E J (2012). Antidiabetic and hypolipidemic activities of ethanolic leaf extract and fractions of Carpolobia lutea. Mol. Clin. Pharmacol., 3: 100- 107.

Alan, L. and Miller, N.D. (1996). Antioxidant flavonoids: structure, function and clinical usage. Alt. Med. Rev., 1: 103-111.

AOAC (2000). Official methods of analysis $\left(17^{\text {th }}\right.$ Edition). Volume 1. Association of Official Analytical Chemists International, Maryland, USA.

Doughari, J.H. (2012). Phytochemicals: Extraction methods, basic structures and mode of action as potential chemotherapeutic agents. In: Rao, V (Ed.), Phytochemicals: A global perspective of their role in nutrition and health, In Tech Open, Rijeka, p 538.

Ettebong E.O., Nwafor, P.A., Ekpo, M. and Ajibesin, K. (2011). Contraceptive, estrogenic and antiestrogenic potentials of methanolic root extract of Carpolobia lutea in rodents. Pak. J. Pharm. Sci., 24(4): 445-449.
Ettebong, E. and Nwafor, P. (2009). Report: In vitro antimicrobial activities of extracts of Carpolobia lutea root. Pak. J. Pharm. Sci., 22: 335-338.

Etukudo, I. (2003). Ethnobotany: conventional and traditional uses of plants. The Verdict Press, Nigeria, p. 83-134.

Hutchinson, J. and Dalziel, J.M. (1954). Flora of West Tropical Africa 1: Crown Agents for Oversea Governments and Administrations. Millbank, London S.W.I p. 108-109.

Iniaghe, O.M., Malomo, S.O. and Adebayo, J.O. (2009). Proximate composition and phytochemical constituents of leaves of some Acalypha species. Pak. J. Nutr., 8: 256-258.

Iwu, M.M. and Ayanwu, B.N. (1982). Phytotherapeutic profile of Nigerian herbs: Antiinflammatory and anti-arthritic agents. $J$. Ethnopharmacol., 6(3): 263-274.

Kamei, H., Kojima, T., Hasegawa, M., Koide, T., Umeda, T., Yukawa, T. and Terabe, K. (1995). Suppression of tumor cell growth by anthocyanins in vitro. Cancer Investigations, 13(6): 590-594.

Kar, A. (2007). Pharmacognosy and pharmacobiotechnology ( $2^{\text {nd }}$ Ed). New Age International Limited Publishers, New Delhi, pp. 332-600.

Karaivanova, M., Drenska, D. and Ovcharov, R. (1990). A modification of the toxic effects of platinum complexes with anthocyanins. Eksperimetnalna Meditsna I Morfologiia, 29(2): 19-24.

Kayode, J. and Omotoyinbo, M.A. (2008). Cultural erosion and biodiversity: conserving chewing stick knowledge in Ekiti State, Nigeria. African Scientist, 9(1): 41-51.

Kubmarawa, D., Khan, M.E., Punah, A.M. and Hassan, M. (2009). Phytochemical and antimicrobial screening of Ficus platyphylla against human/animal pathogens. Pacific J. Sci. Technol., 10(1): $382-386$.

Manfo, F.., Chao, W.F., Moundipa, P.F., Pugeat, M. and Wang, P.S. (2011). Effects of maneb on testosterone release in male rats. Drug. Chem. Toxicol., 34: 120-128. 
Mitaine-Offer, A.C., Miyamoto, T., Khan, I.A., Delaude, C. and Lacaille-Dubois, M.A. (2002). Three new triterpene and saponins from two species of Carpolobia. J. Nat. Prod., 65: 553557.

Muanya, C.A. and Odukoya, O.A. (2008). Lipid peroxidation as index of activity in aphrodisiac herbs. J. Plant Sci., 3: 92-98.

Odebiyi, O.O. and Sofowora, E.A. (1979). Phytochemical screening of Nigerian medicinal plants $2^{\text {nd }}$ OAU/STRC Inter-African symposium on traditional. Pharmaco. Poeia. Afr. Med. Plants, 115: 216-220.

Okwu, D.E. (2001). Evaluation of the chemical composition of indigenous species of flavouring agents. Global. J. Pure Appl. Sci., 7: 455-459.

Olayinka, B.U., Raiyemo, D.A. and Etejere, E.O. (2015). Phytochemical and proximate composition of Tithonia diversifolia (Hemsl.) A. Gray. Annals. Food Sci. Technol., 16(1): 195-200.
Oloyede, O.I. (2005). Chemical profile of unripe pulp of Carica papaya. Pak. J. Nutr. 4(6): 379-381.

Onwuka, G.I. (2005). Food analysis and instrumentation: theory and practice. Naphtali Prints, Surulere, Lagos. p. 219.

Paiva, S. and Russell, R. (1999). Beta carotene and other carotenoids as antioxidants. J. Am. Coll.Nutr., 18: 426-33.

Singhal, A. (2001). Options for non-surgical debridement of necrotic wounds. Adv. Skin Wound Care, 14: 96-100.

Yakubu, M.T. and Jimoh, R.O. (2014). Carpolobia lutea roots restores sexual arousal and performance in parxetine-induced sexually impaired male rats. Rev. Intl. J. Androl., 12: 9099. 